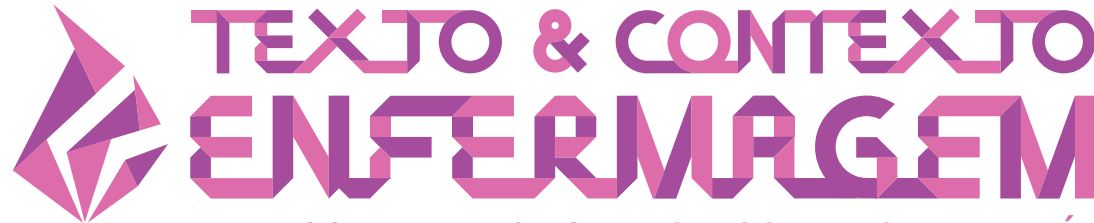

TEXT \& CONTEXT NURSING TEXTO \& CONTEXTO ENFERMERÍA

\section{INSTRUCTIONAL DESIGN FOR NURSING CARE TO NEONATES WITH CONGENITAL HEART DEFECTS}

\author{
Simone da Silveira Magalhães ${ }^{1}$ (1) \\ Edna Maria Camelo Chaves ${ }^{1}$ (D) \\ Maria Veraci Oliveira Queiroz ${ }^{1}$ (D) \\ 'Universidade Estadual do Ceará. Fortaleza, Ceará, Brasil.
}

\begin{abstract}
Objective: to develop and validate instructional design for clinical nursing care to neonates with congenital heart defects in maternities, using distance education.

Method: applied methodological research which consisted of an online course for nurses in neonate units. During the development of the instructional design, the selection and creation of the virtual didactic content were carried out and submitted to internal validation by experts from different areas - Neonatal Nursing, Cardiovascular Nursing, Education, Distance Education, Instructional Design and Informatics. The study followed steps adapted from the instructional design process: analysis (identification and understanding of educational problem), design (specification), development (production), and evaluation (reflection).

Results: nine experts concluded the assessment of the instructional design; six were from the Southeast, two from the Northeast, and one from the South region of Brazil. Seven were higher education professors with experience in education, in addition to their expertise. The Nursing, Education, and Design experts agreed on $91 \%$ of the answers to assessed items for the educational technology, considering it adequate. The experts of informatics obtained an agreement in only $70 \%$ of the assessed items, considering them questionable. The evaluations and recommendations of the experts led to some changes during the creation of the instructional design, prior to the proposal for clinical validation.

Conclusion: the instructional design was approved as per the agreement of the experts' opinions (85\%), and the validation strategy involved different backgrounds, thus qualifying the technology and pointing out the importance of the topic for the qualification of nurses, using distance education resources.
\end{abstract}

DESCRIPTORS: Heart defects congnital. Nursing care. Neonatal nursing. Distance education. Educational technology. Validation studies. 


\section{DESIGN INSTRUCIONAL PARA O CUIDADO DE ENFERMAGEM AOS NEONATOS COM CARDIOPATIAS CONGÊNITAS}

\section{RESUMO}

Objetivo: desenvolver e validar design instrucional para o cuidado clínico de Enfermagem aos neonatos com cardiopatias congênitas em maternidades, por meio de educação a distância.

Método: pesquisa metodológica, aplicada, constituindo-se de curso on-line, para enfermeiros de unidades neonatais. No desenvolvimento do design instrucional efetivou-se a seleção e a elaboração do conteúdo didático virtualizado, submetido à validação interna com juízes de diferentes áreas - Enfermagem Neonatal, Enfermagem Cardiovascular, Educação, Educação a Distância, Design Instrucional e Informática. O estudo seguiu fases adaptadas do processo de design instrucional: análise (identificação e compreensão do problema educacional), design (especificação), desenvolvimento (produção) e avaliação (reflexão).

Resultados: nove juízes concluíram a avaliação do design instrucional, sendo seis da região Sudeste, duas do Nordeste e uma da região Sul do Brasil. Sete deles eram docentes do ensino superior, também com experiências ligadas à educação, além de sua especialidade. Os juízes das áreas da Enfermagem, Educação e Design convergiram em $91 \%$ das respostas aos itens avaliados da tecnologia educativa, considerando-a adequada. Os juízes da área de Informática obtiveram congruência em apenas $70 \%$ dos itens avaliados, considerando-o como questionável. As avaliações e sugestões dos juízes levaram a algumas mudanças na elaboração do design instrucional, antes da proposta de sua validação clínica.

Conclusão: o design instrucional foi validado pela congruência da opinião dos juízes (85\%) e a estratégia de validação incorporou diferentes saberes, qualificando a tecnologia e apontando a importância da temática na capacitação de enfermeiros, com recursos da educação a distância.

DESCRITORES: Cardiopatias congênitas. Cuidados de enfermagem. Enfermagem neonatal. Educação a distância. Tecnologia educacional. Estudos de validação.

\section{DISEÑO INSTRUCCIONAL PARA LA ATENCIÓN DE ENFERMERÍA AL NEONATO CON CARDIOPATÍAS CONGÉNITAS}

\section{RESUMEN}

Objetivo: Desarrollar y validar un diseño instruccional para la atención clínica de enfermería al neonato con cardiopatías congénitas en maternidad, utilizando Educación a Distancia.

Método: Investigación metodológica, aplicada, instituyéndose un curso online para enfermeros de unidades neonatales. En el desarrollo del diseño instruccional se aplicó selección y elaboración del contenido didáctico virtual, sometido a validación interna de expertos de diferentes áreas: enfermería neonatal, enfermería cardiovascular, educación, educación a distancia, diseño instruccional e Informática. El estudio siguió etapas adaptadas del proceso de diseño instruccional: análisis (identificación y comprensión del problema educativo), diseño (especificación), desarrollo (producción) y evaluación (reflexión).

Resultados: Nueve expertos concluyeron la evaluación del diseño instruccional, representando seis a la región Sudeste, dos al Noreste y una de la región Sur. Siete de ellos eran docentes de enseñanza superior, también con experiencia vinculada a la educación, además de su especialidad. Los expertos de enfermería, educación y diseño concordaron en el $91 \%$ de respuestas a los ítems evaluados en la tecnología educativa, considerándola adecuada. Los expertos en informática concordaron solo en el $70 \%$ de los ítems evaluados, considerándola cuestionable. Las evaluaciones y sugerencias de los expertos provocaron algunos cambios en la elaboración del diseño instruccional antes de la propuesta de su validación clínica.

Conclusión: El diseño instruccional fue validado por concordancia de opinión de los expertos (85\%). La estrategia de validación incorporó diferentes saberes, calificando la tecnología y destacando la importancia de la temática en la capacitación de enfermeros con recursos de educación a distancia.

DESCRIPTORES: Cardiopatías congénitas. Atención de enfermería. Enfermería Neonatal. Educación a distancia. Tecnología educacional. Estudios de validación. 


\section{INTRODUCTION}

Congenital heart defects account for $24 \%$ of deaths of babies born with heart defects. Every year, nearly 4,800 neonates are born with one of the seven severe congenital heart defects, with a high risk of death and disabilities if they are not diagnosed and treated in a timely manner. ${ }^{1}$

Newborns with severe heart diseases may remain stable during the first days of life. Upon hospital discharge, they may be asymptomatic, but decompensate rapidly in days or weeks. The diagnosis and immediate treatment in the neonatal period prevent hemodynamic deterioration and lesions to other organs, especially the central nervous system, improve the prognostic, and reduce morbidity and mortality rates. However, many babies do not reach specialized centers in time to receive proper treatment. ${ }^{2-4}$

It is important to emphasize that maternities are not centers specialized in cardiology. Professionals that work in these institutions need qualification to provide care to this population, in order to keep the neonates with heart diseases in the best possible health conditions until the moment to refer them to a specialized hospital, thus helping to reduce avoidable deterioration and complications.

During nursing care training since graduation, specialization or even ongoing education, care to neonates with congenital heart defects has not been systematically addressed with the use of digital technologies, which in turn could encourage professionals to participate in the teachinglearning process. Therefore, there is a need to provide training and, in the current context, it should be taken into account that education and technology go hand in hand. In this scenario, the integration of these sciences is not perceived as a mere possibility, but rather a need as a current cultural and communication mode that provides new dynamic and creative forms of learning, regardless of the teaching method, whether on-site or not, with differentiated pedagogic strategies. ${ }^{5}$

As a result, the use of distance education (DE) has been growing in terms of training and qualification of healthcare professionals at varying levels in the context of the Brazilian Unified Health System (SUS, as per its acronym in Portuguese). However, this modality must not be taken only as an alternative, but as a new teaching and learning method capable of facilitating collaborative learning networks, as well as strengthening management and co-management spaces and the conversion of individuals and their realities, in a way that could lead to improvement of the services offered to the population. ${ }^{6}$

Therefore, the possibility of promoting teaching and learning is to make DE available in the digital modality, applying the instructional design resource. "With online education, instructional design has the purpose of planning, preparing, projecting, producing, and publishing texts, images, graphics, sounds and movements, simulations, activities, and tasks backed up by virtual support." "2 In addition to the human capacity to deal with Information and Communication Technologies (ICTs) and technological infrastructure, DE and instructional design depend on proposed educational objectives, meeting the needs of structured educational initiatives. ${ }^{7}$

Therefore, interest grew for carrying out development research and validation of technology to expand scientific knowledge of nurses in neonatal units and/or maternities, which could contribute to the clinical practice, mediated by scientific evidence and the use of ICTs. As a result, the present research objective was to develop and validate instructional design for clinical nursing care to neonates with congenital heart defects in maternities, using distance education. 


\section{METHOD}

Applied methodological research was developed, consisting of the development and validation of instructional design - an online course using DE for nurses of neonatal units that provide care to babies with congenital heart defects. The study followed steps adapted from the instructional design process - analysis (identification and comprehension of the educational problem), design (specification), development (production), implementation (action), and evaluation (reflection). ${ }^{8}$ For this article, the implementation step was excluded, because it corresponded to the course delivery. Figure 1 shows the research steps.

In the initial step, the didactic content was selected and created through integrative ${ }^{9}$ and narrative reviews, including a search in the literature available on the topic (books, theses, and other official publications from the Health Ministry). ${ }^{2,10-13}$ The didactic content was created with an attempt to explore the topic, as a collective and broadened approach, in order to identify and understand the educational problem. This stage may be considered similar to the analysis of the instructional design process. Videos and links related to the topic and freely available on the internet were also collected. In addition to the didactic content, other activities were carried out for better interaction and communication among participants: a discussion forum, a case study, and an online system to followup the participants, their input, availability of their evaluations, and tools for message exchange. This structure and content planning of the instructional design, according to the chosen digital platform standard, corresponds to the specifications set up by the instructional design process.

In the next step, the created instructional design content was virtualized and assigned to the Solar Platform, the Virtual Learning Environment (VLE) of the UFC Virtual Institute, at the Federal University of Ceará (UFC, as per its acronym in Portuguese), according to the official release to

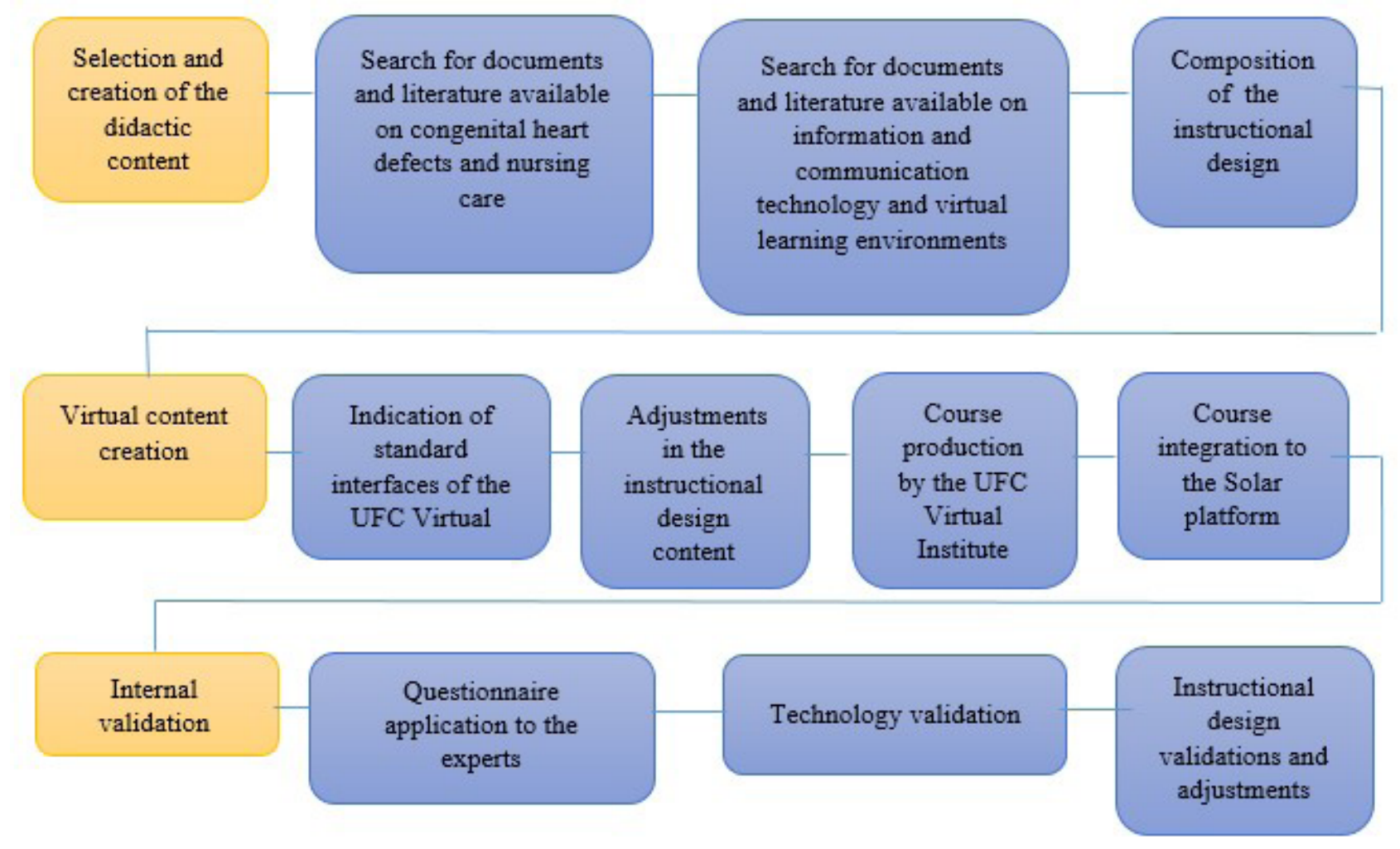

Figure 1 - Steps of the methodological research for the development and validation of the instructional design. 
access the Solar Platform for use in courses, which was signed by the researchers and the referred institute board. In-person and online communication took place with the designer responsible for the referred institute, who willingly received and made adjustments to the platform content. This creation corresponds to the development (production) of the instructional design process.

Subsequently, the internal validation of the technology was carried out with the submission of the instructional design to the experts in the care of neonates with congenital heart defects (Neonatal Nursing and/or Cardiovascular Nursing), in education and/or DE, instructional design, and professionals in the Informatics (IT) area with experience in ICTs. This step can be compared to the evaluation (reflection) of the instructional design process.

The experts were asked to validate the created educational technology content. Content validation is an assessment by a group of independent specialists, without the need to rely on methods totally objective to perform the task. ${ }^{14}$ The participants selected for the validation consisted of nine professionals, ${ }^{15}$ who were chosen based on their expertise, while others ${ }^{16}$ were adapted as follows: masters (two points); masters with thesis content relevant to the topic (one point); studies and/or publications in the area (two points); articles published in journals with Qualis>B2 (two points); PhDs (four points); minimum of one year in the practice (one point); and certification (specialization) in the area with proven practice (two points). Based on this scoring system for research inclusion, the professionals had to obtain a minimum score of five points in the panel of specialists.

The search for participants was conducted using snowball sampling, also called network sampling ${ }^{14}$ initiated with the Lattes Platform. After identifying the experts, an invitation letter was sent via email. A total of 33 letters were sent, with 16 being accepted, 1 refused, and 16 letters were not replied. After acceptance, a new email was sent with instructions for registration and navigation in the Solar Platform, the informed consent form for approval to participate in the research as an expert, and the link to the instructional design evaluation questionnaire, which should be answered within 20 days after agreement. Of the total, just nine concluded the evaluation, and became the research participants. At the end of this stage, a statement of participation, signed by the researchers, was also sent to the experts via email.

The questionnaire for the educational technology validation addressed the characterization of the experts and different aspects of their assessments, according to each group of experts. The education, DE, instructional design, neonatal nursing and/or cardiovascular nursing experts assessed the educational aspects of the technology (relevance, objectives, texts/hypertexts, activities, assessment tools and methods, student autonomy, and didactic resources), the technology interface (navigability, presentation, and screen designs), as well as didactic resources (interactivity, resource presentation, and activities). Meanwhile, the IT experts assessed the response time (navigability, accessibility, and feedback of the tests), interface quality (visual aspect), and tools and resources (display format and performance). The recurring items in the questionnaire were based on a similar tool used in the study that developed and assessed a VLE on cardiopulmonary resuscitation in neonatology. ${ }^{17}$

The questionnaire for assessment of the technology by the experts used a Likert scale with a score from one to four, ${ }^{15}$ in which: $1=$ Inadequate; $2=$ Partially adequate; $3=$ Adequate; $4=$ Totally adequate. The data analysis for the technology validation was carried out by matching the opinions of the experts, called by the researchers as content validity index (CVI). ${ }^{14}$ The CVI measures the rate or percentage the experts are in agreement on specific aspects of the tool, thus allowing the analysis of each item separately and, then, the tool as a whole. ${ }^{18}$ The questionnaires also included a space for comments and suggestions, which could be addressed by the experts. 
The CVI score was calculated by the number of answers 3 and 4 in relation to the total number of answers. ${ }^{19}$ According to this calculation, items with a matching higher than $79 \%$ were considered adequate, between $70 \%$ and $79 \%$ as questionable, and lower the $69 \%$ as unacceptable, taking into account that a $\mathrm{CVI}$ of 0.90 is considered as the standard to establish the optimum content validity of a scale..$^{14,18}$ The scores were calculated and presented in tables. After this stage, the suggestions made by the experts were accepted and sent as changes to the designer at the UFC Virtual Institute and, finally, the creation of the instructional design was concluded.

All ethical procedures set out by the informed consent form were met as autonomy, risks, and benefits of the research.

\section{RESULTS}

Of the nine experts that concluded the instructional design assessment, three were from the IT area and six related to other areas (neonatal or cardiovascular nursing, education, DE, and instructional design). All of them worked in Brazil. One expert was from the state of Ceará, five were from São Paulo, one from Santa Catarina, one from Minas Gerais, and one from Pernambuco.

The nursing, education, and instructional design experts were all female, with a mean age of 41 years. There were three nurses, two were educational designers, and one pharmacist, of whom five were higher education professors with experience in educational technology and DE. The only one who was not a professor was a nurse specialized in cardiovascular nursing and responsible for the continuing education of a major hospital in the country. The mean training time of this group of experts was approximately 17 years, with a major area of activity in education, holding an average of 12 years of professional practice; $50 \%$ had a Ph.D. and $50 \%$ had a master's degree. Five developed graduation end-of-course papers with topics related to the study, while the sixth participant had a specialization in continuing distance education and trained SUS personnel, with publication in a scientific journal on the subject. It is important to point out that all of them had scientific publications related to the study subject. Among the participants, $83 \%$ are members of research groups, including the "Center for Telematic Studies and Research in Healthcare."

The mean age of the IT experts was 42 years, and they were predominantly female. Two of them were also involved in education as higher education professors. Their mean training time in the field was 20 years, with experience related to digital media and systems, and mean working time of 18 years. They all held graduate degrees, whereas two held PhDs and one had a master's degree. Three had dissertations and theses related to the study subject and one had a publication in a scientific journal, also related to the subject. The experts participated in research groups, and one of them worked on the topic "Innovating technologies and practices applied to education."

The instructional design consisted of five classes with a total of course load of 80 hours, including a discussion forum for the participants. Each class offered a related-activity to be carried out by the participant and a pre-test prior to the beginning of the course and a post-test at the end to evaluate the acquisition of knowledge by the participants. The classes were prepared with texts, scientific articles, videos, sounds, graphics, and images supported by the Solar VLE.

Regarding the design validation (222 answers), the experts assessed the items shown in tables 1 and 2 (203 answers), making comments and providing suggestions.

Despite the results showing that the experts considered the instructional design adequate (agreement $>79 \%$ ) by the CVI calculation, the suggestions were accepted, leading to changes in the educational technology. Regarding the course content, the experts assessed it as excellent and relevant, based on the current literature and properly shared by different media (infographics, images, 
Table 1 - Instructional Design assessment by Neonatal Nursing, Cardiovascular Nursing, education, DE, and Instructional Design experts regarding the educational aspects, environment interface, and didactic resources. Fortaleza, Ceará, Brazil, 2017. $(n=6)$.

\begin{tabular}{|c|c|c|}
\hline Variables & n (answers 3 and 4 ) & $\mathrm{CVI}^{*}$ \\
\hline Educational aspects & 102 & 0,89 \\
\hline Topic relevance & 6 & 1.0 \\
\hline Objectives & 5 & 0.83 \\
\hline Course load - 80h & 5 & 0.83 \\
\hline Texts/Hypertexts - classes & 6 & 1.0 \\
\hline Depth of contents/approach & 6 & 1.0 \\
\hline Clarity & 6 & 1.0 \\
\hline Coherence & 6 & 1.0 \\
\hline Relevance of terminology & 6 & 1.0 \\
\hline Concept update and precision & 6 & 1.0 \\
\hline Relevance of the links & 6 & 1.0 \\
\hline Background of the activities & 5 & 0.83 \\
\hline Updated and relevant references & 4 & 0.66 \\
\hline Coherence of the activities & 5 & 0.83 \\
\hline Level of demand of the activities & 5 & 0.83 \\
\hline Number of proposed activities & 5 & 0.83 \\
\hline Types of proposed activities & 5 & 0.83 \\
\hline Range of the objectives of the activities & 5 & 0.83 \\
\hline Evaluation & 5 & 0.83 \\
\hline Autonomy of the participant & 5 & 0.83 \\
\hline Environment interface & 46 & 0.95 \\
\hline Navigability & 6 & 1.0 \\
\hline Accessibility & 6 & 1.0 \\
\hline Menu & 6 & 1.0 \\
\hline Buttons - highlight & 6 & 1.0 \\
\hline Screen design & 5 & 0.83 \\
\hline Colors & 6 & 1.0 \\
\hline Font & 5 & 0.83 \\
\hline Information density & 6 & 1.0 \\
\hline Didactic resources & 55 & 0.91 \\
\hline Interactivity & 6 & 1.0 \\
\hline Figures & 6 & 1.0 \\
\hline Photos & 6 & 1.0 \\
\hline Videos & 5 & 0.83 \\
\hline Sounds & 5 & 0.83 \\
\hline Texts & 6 & 1.0 \\
\hline Animations & 5 & 0.83 \\
\hline Links & 6 & 1.0 \\
\hline Portfolio & 5 & 0.83 \\
\hline Forums & 5 & 0.83 \\
\hline Total & 203 & 0.91 \\
\hline
\end{tabular}

${ }^{*} \mathrm{CVl}$ : content validity index. 
Table 2 - Instructional Design assessment by the IT experts regarding response time, interface quality, tools, and resources. Fortaleza, Ceará, Brazil, 2017. $(n=3)$.

\begin{tabular}{|c|c|c|}
\hline Variables & n (answers 3 and 4$)$ & $\mathrm{CVI}^{*}$ \\
\hline Response time & 17 & 0.80 \\
\hline Navigability & 3 & 1.0 \\
\hline Accessibility & 2 & 0.66 \\
\hline Boot process & 2 & 0.66 \\
\hline Software exit & 3 & 1.0 \\
\hline Display next screen & 3 & 1.0 \\
\hline Display previous screen & 2 & 0.66 \\
\hline Feedback of the tests & 2 & 0.66 \\
\hline Interface quality & 40 & 0.70 \\
\hline Use of space & 2 & 0.66 \\
\hline Screen format & 2 & 0.66 \\
\hline User-friendly & 2 & 0.66 \\
\hline Design & 1 & 0.33 \\
\hline Navigation buttons & 2 & 0.66 \\
\hline Color scheme & 2 & 0.66 \\
\hline Figures & 1 & 0.33 \\
\hline Photos & 1 & 0.33 \\
\hline Videos & 3 & 1.0 \\
\hline Sounds & 3 & 1.0 \\
\hline Texts & 3 & 1.0 \\
\hline Menu - layout & 3 & 1.0 \\
\hline Menu - sequence & 3 & 1.0 \\
\hline Internal links & 3 & 1.0 \\
\hline External links & 3 & 1.0 \\
\hline Buttons - highlight & 1 & 0.33 \\
\hline Font & 2 & 0.66 \\
\hline Letterheads & 2 & 0.66 \\
\hline Information density & 1 & 0.33 \\
\hline Tools and resources & 6 & 0.50 \\
\hline Forum & 1 & 0.33 \\
\hline Animation & 2 & 0.66 \\
\hline Links & 2 & 0.66 \\
\hline Email - messages & 1 & 0.33 \\
\hline Total & 63 & 0.70 \\
\hline
\end{tabular}

${ }^{*} \mathrm{CVI}$ : content validity index.

videos, and scientific articles). The instructions for environment functionality were considered fully understood, with the presentation of concepts in the form of texts, tables, illustrations, and animations in a didactic format. Among the comments, the following was highlighted: "Topic of major relevance for nurses; the use of DE is a path to increase access to professional training opportunities." One of the experts considered the content too long, but relevant and important, and added that the interactive approach was a way to attract the interest of professionals. 
One expert suggested improving the clarity of the objectives, and keeping them at the beginning of each class. Regarding the course load, the recommendations for this modality of DE were that the average ratio for the participant reading time be made by a number of pages, in which two pages (pages in A4) should correspond to one DE hour. Therefore, the total course load was recalculated, taking into account the attached documents for the composition of the educational technology, videos, scientific articles indicated for reading, as well as the time that should be made available for carrying out the tasks. Another suggestion made by the same expert was the opportunity for the participants to engage in self-assessment, which leads to more autonomy at the end of the course.

Two experts complimented the availability of the texts intertwined with videos and graphics, including the font colors and desktop background (fonts in black color and blue highlights), which promoted a smooth and comprehensible reading, thus minimizing fatigue. Those inputs were challenged by another expert, who proposed that light colors could lead to relaxation and attention dispersion. The experts praised the VLE and the possibility to access it through mobile devices, which promoted interactivity and different reading/visualization formats for learning.

Finally, one expert in this group suggested a change in the images used in the instructional design and considered that, although they were all properly referenced to the source, problems could arise regarding copyrights, since some consulted sites were not the right holders of the images. The expert indicated images from public domain websites and repositories of learning material for these educational purposes, which minimize the risk of image copyright infringement. Following this suggestion, the design was changed.

Table 2 shows the assessment of the institutional design by the IT experts ( 63 answers with score 3 and 4 from the 90 answers obtained).

Regarding the assessment of another group of experts, the IT professionals assessed many instructional design items as questionable and some even unacceptable. However, these items were more related to the operation of the VLE itself, such as the highlight buttons and email messages available in the digital platform. The results were discussed with the designer who virtualized the course content in the VLE and, after the possible course-related changes being made, the suggestion was accepted by an expert, who said the following: "The menu layout should be aligned and fixed in the upper part. This way, more space would be made available and, consequently, the text font could be amplified, since in many links it is too small. Photos and illustrations could also be better viewed with the screen widened horizontally."

\section{DISCUSSION}

The constant changes in the healthcare sector and job market demand more professional growth with the acquisition of knowledge, technical and interpersonal skills, and a critical and reflective attitude, which can expand the skills for the already developed activities. ${ }^{20}$

This study showed the relevance of several continuing education methods for healthcare workers, based on both the studies carried out ${ }^{6,17,20-21}$ and the comments made by the experts. Therefore, it confirms that continuing education is a great tool to meet the educational needs of professionals in the healthcare setting, in which DE is a practical training strategy that allows reaching a large number of people. ${ }^{20}$

The study participants, referred to as experts and specialists in several areas, were mostly women from the education field with expertise on the topic that was assessing the technology, including experience in scientific production or similar. The importance of this diversity, along with the approach 
of the experts with the topic, is key to the DE pedagogical proposals. It leads to a cooperative and constructivist environment for learning that tries to break away from the positivism evidenced in undergraduate courses, enables a horizontal relationship between professors and students, and leads to the creation of collaborative networks for interaction and learning. ${ }^{6}$

Regarding the participation of the experts, their recommendations for the instructional design format and content were important to make the adjustments and adequacies to the target-population, notably for nurses from neonatal units, which led to the next step of the research. This was the assessment of the technology with these subjects with an aim at their training, concomitantly with the external evaluation of the instructional design mediated by the DE course.

The DE modality has helped to improve the teaching-learning process, because it provides educational opportunities to people with difficulty in having access to education, due to poor financial conditions, time and physical displacement, and also offers flexibility and convenience through dynamic, interactive and technological tools, at the same time it demands commitment from students. ${ }^{22}$

The results confirmed the comments experts made as they assessed the adjusted instructional design, whether regarding the importance of the topic for the professional training of nurses from neonatal units or the possibility of being carried out by DE. Namely, the virtual approach was a means to enable the involvement of those at the job market, and who many times face limitations to perform their tasks.

One of the instructional design specialists, who was graduated in biology, taught a 28-hour extension course in congenital heart defects and made a comment regarding the clarity of the concepts and its didactic presentation in the format of texts, tables, illustrations, and animations. This assessment sought to meet the recommendations scholars provided, in which the didactic material should focus on interactivity to facilitate and expand learning in a dynamic fashion, to promote student autonomy, thus developing their intellectual, reflective, creative, critical, and productive abilities. ${ }^{23}$

Therefore, the objective of the instructional design is to be simple and clear, although comprehensive enough to provide support to clinical nursing care, based on evidence-based practice. The uniqueness of nursing care to neonates with congenital heart defects creates the need for evidencebased practice; therefore, it is up to nurses to collect better evidence to guide their actions, due to the amount and complexity of information produced and published on healthcare on a daily basis. ${ }^{24}$ In addition, Brazilian healthcare practices and policies show limited intervention experiences based on evidence. This practice helps professionals, such as nurses, to become more critical-reflective, thus leading to the development of innovations in clinical contexts and improved healthcare results. ${ }^{25}$

The importance of tools, such as the instructional design and DE itself for neonatal nursing, is even greater when authors make comments regarding strategies for this range of activity and teaching. It minimizes the exposure of the neonatal population, reduces the risks related to clinical trials, and narrows the gap between professional and academic theory and practice. It also establishes a closer relationship with the real context and provides advantages to expand knowledge and costeffectiveness, whether in terms of training or continuing education. ${ }^{21}$

In line with the literature, the educational objectives and didactic resources of the assessed educational technology were evaluated by the group of nursing, education, DE, and design experts as adequate, meeting what authors expect on the need for a selection of technological resources aligned with the educational goals proposed for the development of a discipline or a course. ${ }^{26}$

Regarding interface quality for the course allocated in the Solar VLE, the group of nursing, education, DE, and design experts had a 95\% agreement in their answers, in contrast with the group of IT experts, which had a $70 \%$ agreement in their answers, thus deeming the interface evaluation as questionable. This difference may lead to the assumption that the IT experts are more demanding on 
items that other experts considered suitable, taking into account that they perceive other significant points, such as content and the design itself, serving to the training purposes. This finding corroborates the literature, ${ }^{20}$ which implies that not all professionals have skills to use virtual tools, so such skills should be developed to deal with new technologies, which in turn could also happen with professionals involved in the validation of educational technology.

Regardless of the cause, all questionable or even unacceptable items in the assessment of the IT experts, including the suggestions that they agreed upon, led to changes in the instructional design. However, most items, to which the experts did not add any suggestion, kept the original design, because the intention was to continue with the clinical educational technology validation, a stage that was subsequently carried out with the offer of the online course for nurses from neonatal units who, often, provide care to babies with congenital heart defects.

Different viewpoints on the same technology led to many contributions and, as a result, helped to improve the instructional design. This knowledge exchange proposal is sustained by authors ${ }^{6,27}$ that perceive the need for investments in personnel training and qualification for the current understanding of the healthcare system, through more opened and multidisciplinary curricula, with skills and practices based on collaboration.

The result of distinct knowledge is also evidenced in other aspects of the subjects: social, affective, cultural, and economic, among others. Therefore, since this multidimensionality considers subject and society as complex entities, this acknowledgment must pave the way to a globalized method of teaching and learning. The DE proposal in the current context is backed up by this globalized teaching and learning model. ${ }^{6}$

As the design was created with subsequent validation by the experts, the study limitations were the difficulty to get the evaluations returned from them. However, the collaboration of those who returned them was invaluable, and helped to expand horizons to improve the teaching-learning technology and provided a glimpse to plenty of possibilities for professional training with the use of DE, mediated by ICTs, with a range of knowledge in neonatal nursing. Thus, the validation of the instructional design was considered an important contribution that will provide a professional training opportunity for the qualification of neonatal care, essentially for providing care to babies with congenital heart defects and with chances to survive with quality, relying on professional skills and other associated factors.

\section{CONCLUSION}

The validation of the instructional design was concluded with the assessment of two different groups of experts who contributed to the improvement of the technological resource through the implementation of an array of multidisciplinary knowledge on healthcare, education, and disciplines in the field of technologies.

Although the results of the CVIs from the two distinct groups of experts had been different, the resulting $\mathrm{CVI}$ of the participants jointly was 0.85 , thus reaching the adequate value for its validation. Therefore, by combining the opinion of the experts, the instructional design was validated and their suggestions helped to improve the aspects that were within the reach set by the researchers and collaborators.

This result reinforced the need for the clinical validation of the educational technology, which is a stage that corresponds to the implementation (action) of the instructional design process. Therefore, the validation strategy among different professionals, including the technology qualification, showed its importance for the qualification of nurses with DE resources. 
However, some setbacks had to be overcome, such as difficulties using the digital platform itself, lack of scientific articles directly related to the topic, content virtualization (colors, structure, VLE standard, among others), the return of the assessment carried out by the experts in a timely manner, and other obstacles that emerged along the way. Yet, they were solved during the development of the technology and its validation.

The course was relatively easy to set up, since the main author has a close relationship with the topic, since she is a neonatal nurse and has experience with the flow of patients with congenital heart defects in the maternities and the aspects of this specialized care. In addition, she has knowledge in the main learning setbacks related to the topic presented by professionals in practice, which also led to the choice of contents that could fill the gap found in the literature reviews. This experience further helped to create the online course, and guided some priorities to the addressed care.

The development of the research and the format of the instructional design are tools available for professional improvement in the care of neonates with congenital heart defects in maternities. Its contribution lies on the possibility of encouraging nurses to use and develop new technologies to be applied to their clinical practices, backed up by ICTs and DE, with personal growth and, as a result, professional advancement.

The use of ICTs and DE is a new path and opportunity for professional qualification, since these groundbreaking educational resources benefit professionals who are already working with nursing care, adjusting their time and enabling their professional qualification.

\section{REFERENCES}

1. Livolsi K, Bowman DS. Implementing a screening program for congenital cardiac defects in newborns in a community Hospital setting. J Obstet Gynecol Neonatal Nurs Washington. 2014;43 Suppl 1:S39.

2. Ministério da Saúde $(B R)$. Atenção à saúde do recém-nascido: guia para os profissionais de saúde. 2nd ed. Brasília (DF): MS, Secretaria de Atenção à Saúde. Departamento de Ações Programáticas Estratégicas; 2014. v.3

3. Simpson E, Culp S. Do You Know Who's at Risk? Screening for critical congenital heart disease using pulse oximetry. J Obstet Gynecol Neonatal Nurs. 2013;42 Suppl 1:S31-2.

4. Loyot CA, Palmer CA. Fast Track Initiation of a Congenital Heart Disease Screening Program. J Obstet Gynecol Neonatal Nurs. 2013;42 Suppl 1:S38.

5. Gama LN, Tavares CMM. Educação e mídias: implicações contemporâneas no cotidiano acadêmico. Texto Contexto Enferm. [Internet]. 2015 June [cited 2018 Feb 15];24(2):593-9. Available from: https://dx.doi.org/10.1590/0104-07072015002052014

6. Vargas FMA, Trindade MCN, Gouveia GDA, Farias MR. A educação a distância na qualificação de profissionais para o sistema único de saúde: meta estudo. Trab Educ Saúde [Internet]. 2016 [cited 2018 Feb 15];14(3):849-70. Available from: https://dx.doi.org/10.1590/1981-7746-sol00018

7. Filatro A, Piconez SCB. Design instrucional contextualizado. In: $11^{\circ}$ Congresso Internacional de EaD: Avaliação - compromisso para a qualidade e resultados e $1^{\circ}$ encontro de Educação a Distância dos Países de Língua Portuguesa, 2004; Salvador, Brasil. Salvador (BA): EaD; 2004 [cited 2018 Feb 15]. Available from: http://www.abed.org.br/congresso2004/por/pdf/049-tc-b2.pdf

8. Filatro A. Design instrucional na prática. São Paulo (SP): Pearson Education do Brasil;2008.

9. Magalhães SS, Queiroz MVO, Chaves EMC. Neonatal nursing care of the infant with congenital heart disease: an integrative review. Online Braz J Nurs [Internet] 2016 Dec [2017 Nov 16];15(4):72434. Available from: http://www.objnursing.uff.br/index.php/nursing/article/view/5415 
10. Croti UA, Mattos SS, Pinto Jr VC, Aiello VD. Cardiologia e cirurgia cardiovascular pediátrica. São Paulo (SP): Roca;2008.

11. Tamez RN, Silva MJP. Enfermagem na UTI Neonatal: assistência ao recém-nascido de alto risco. Rio de Janeiro (RJ): Guanabara Koogan;2013.

12. Pinto Jr VC. Cardiopatias congênitas: rede de atenção à saúde. Fortaleza (CE): Valdester Cavalcante Pinto Júnior;2015.

13. Pinto Júnior VC. Avaliação da Política Nacional de Atenção Cardiovascular de Alta Complexidade com foco na cirurgia cardiovascular pediátrica [dissertação]. Fortaleza (CE): Universidade Federal do Ceará, Curso de Mestrado em Avaliações de Políticas Públicas;2010.

14. Polit DF, Beck CT. Fundamentos da pesquisa em Enfermagem. 7th ed. Porto Alegre (RS): Artmed; 2011.

15. Teixeira E, Mota VMSS, editors. Tecnologias educacionais em foco. São Caetano do Sul (SP): Difusão Editora; 2011.

16. Fehring R. The Fehring Model. In: Carrol-Johnson RM, Paquette M. editors. Classification of nursing diagnoses: proceedings of the tenth conference. Philadelphia (US): JB Lippincott - North American Nursing Diagnosis Association; 1994. p.55-62.

17. Rodrigues RCV. Ambiente virtual de aprendizagem em reanimação cardiorrespiratória em Neonatologia [dissertação]. São Paulo (SP): Universidade de São Paulo, Programa de PósGraduação da Escola de Enfermagem da Universidade de São Paulo;2008.

18. Alexandre NMC, Coluci MZO. Validade de conteúdo nos processos de construção e adaptação de instrumentos de medidas. Ciênc Saúde Coletiva [Internet]. 2011 Jul [cited 2018 Feb 15];16(7):30618. Available from: https://dx.doi.org/10.1590/S1413-81232011000800006

19. Hyrkäs K, Appelqvist-Schmidlechner K, Oksa L. Validating an instrument for clinical supervision using an expert panel. Int J Nurs Stud [Internet]. 2003 [cited 2017 Oct 10];40(6):619-25. Available from: https://doi.org/10.1016/S0020-7489(03)00036-1

20. Silva AN, Santos AMG, Cortez EA, Cordeiro BC. Limites e possibilidades do ensino à distância (EaD) na educação permanente em saúde: revisão integrativa. Ciênc Saúde Coletiva [Internet]. 2015 Apr [cited 2018 Feb 16];20(4):1099-107. Available from: https://dx.doi.org/10.1590/141381232015204.17832013

21. Freire LM, Paula MA, Duarte ED, Bueno M. Educação a distância no cenário da enfermagem neonatal: revisão sistemática. Rev Esc Enferm USP [Internet]. 2015 Jun [cited 2018 Feb 15];49(3):508-14. Available from: https://dx.doi.org/10.1590/S0080-623420150000300021

22. Marchisotti GG, Oliveira FB, Lukosevicius AP. The social representation of distance education from a Brazilian perspective. Ensaio: Aval Pol Públ Educ [Internet]. 2017 Sept [cited 2018 Feb 15];25(96):743-69. Available from: https://dx.doi.org/10.1590/s0104-40362017002500860

23. Costa JW, Grossi MGR, Silva ER. Design para EaD: metodologia recursiva para produção de materiais didáticos. Poiésis - Rev Programa de Pós-Graduação em Educação (Unisul). [Internet] 2016 Jun/Dec [cited 2018 Feb 10];10(Spe):84-96. Available from: https://dx.doi.org/10.19177/ prppge.v10e0201684-96

24. Ercole FF, Melo LS, Alcoforado CLGC. Revisão integrativa versus revisão sistemática [editorial]. Rev Min Enferm [Internet]. 2014 Jan/Mar [cited 2018 Feb 10];18(1):12-4. Available from: https:// www.dx.doi.org/10.5935/1415-2762.20140001

25. Acosta AM, Oelke ND, Lima MADS. Theoretical considerations of deliberative dialogue: contributions for nursing practice, policy and research. Texto Contexto Enferm [Internet]. 2017 [cited 2018 Feb 15];26(4):e0520017. Available from: https://dx.doi.org/10.1590/0104-07072017000520017 
26. Avelino CCV, Borges FR, Inagaki CM, Nery MA, Goyatá SLT. Development of a course in the Virtual Learning Environment on the ICNP®. Acta Paul Enferm [Internet]. 2016 Feb [cited 2018 Feb 16];29(1):69-76. Available from: http://dx.doi.org/10.1590/1982-0194201600010

27. Dias MAS, Vieira FMBR, Silva LCC, Vasconcelos MIO, Machado MFAS. Inter-professional collaboration in the 'Health and Prevention in Schools' Project. Ciênc Saúde Coletiva [Internet]. 2016 Jun [cited 2018 Feb 15];21(6):1789-98. Available from: https://dx.doi.org/10.1590/141381232015216.08112016 


\section{NOTES}

\section{CONTRIBUTION OF AUTHORITY}

Study design: Magalhães SS.

Data collect: Magalhães SS.

Data analysis and interpretation: Magalhães SS, Chaves EMC.

Discussion of the results: Magalhães SS, Chaves EMC, Queiroz MVO.

Writing and / or critical review of content: Magalhães SS, Chaves EMC, Queiroz MVO.

Review and final approval of the final version: Magalhães SS, Queiroz MVO.

\section{ETHICS COMMITTEE IN RESEARCH}

Approved by the Ethics Committee in Research with Human Beings of the Universidade Estadual do Ceará no. 1.601.068, and Certificate of Presentation for Ethical Appreciation 55195416.7.0000.5534

\section{CONFLICT OF INTEREST}

There is no conflict of interest.

\section{HISTORICAL}

Received: February 24, 2018

Approved: June 12, 2018

\section{CORRESPONDENCE AUTHOR}

Simone da Silveira Magalhães

sisimagalhaes@yahoo.com.br 